\title{
Phytochemical, Antimicrobial, Anthelminthic and Antidiarroheal Activity of Traditional Plant Randia uliginosa Retz
}

\author{
MD Hossain $\mathbf{S}^{1}$, MD Al-Amin ${ }^{2 *}$, MD Hossain A $^{3}$ and MD Rana $\mathbf{S}^{2}$
}

${ }^{1}$ Department of Pharmacy, Prime Asia University, Banani, Dhaka, Bangladesh

${ }^{2}$ Department of Pharmacy, Jahangirnagar University, Savar, Dhaka, Bangladesh

${ }^{3}$ Department of Pharmacy, Daffodil International University, Dhaka, Bangladesh

\begin{abstract}
The present study was designed to evaluate the phytochemical, antimicrobial, antidiarroheal, anthelminthic activity of methanol, chloroform and petroleum ether extract of whole plant of Randia uliginosa Retz. (Family- Rubiaceae) by in vivo and in vitro test. Different crude extracts of Randia uliginosa Retz. have been shown to possess phytoconstituents including carbohydrates, alkaloid, glycosides, steroids, tannins and saponin. Concentration $50 \mathrm{mg} / \mathrm{mL}$ of methanol extract showed maximum anthelminthic activity which is comparable to the standard (Piperazine Citrate, 10 $\mathrm{mg} / \mathrm{mL}$ ). Methanol extract of $R$. uliginosa at a dose of $30 \mu \mathrm{L} / \mathrm{disc}$ showed maximum antimicrobial activity. Significant $(p<0.01)$ level of reduction in fecal dropping was found in $250 \mathrm{mg} / \mathrm{kg}$ methanol extract and highly significant at $500 \mathrm{mg} / \mathrm{kg}$ methanol extract. The maximum inhibition of defecation $56.98 \%$ is observed in $500 \mathrm{mg} / \mathrm{kg}$ extract which is comparable to standard Loperamide. These data demonstrate that the plant may contain bioactive compounds possessing antimicrobial, antidiarroheal and anthelminthic activities.
\end{abstract}

Keywords: Randia uliginosa Retz; Antidiarroheal; Anthelminthic; Antimicrobial

\section{Introduction}

Traditional medicine is an important source of potential drugs for contemporary applications in various infectious diseases. Natural products have played an important role as new chemical entities. Between 1981 and 2002 approximately $28 \%$ of new chemical entities of medicine were natural product-derived [1]. Koehn and Carter in their research paper found that natural products provide a starting point for new synthetic compounds, with diverse structures and often with multiple stereo centers that can be challenging to derive synthetically [2].

An important change in resistance prevalence rates has occurred with the shift from Gram-positive to multi-resistant Gram-negative bacteria, for which treatment options are limited or entirely lacking which excelled the search for new antimicrobial principles in traditional medicinal plants [3]. The alkaloids present in the plants may be responsible for the antibacterial activity [4]. The antimicrobial activity may also be due to the presence of flavonoids [5], saponins [6], steroids [7]. The plant extracts are specially tested in drug-resistant organisms to get a more effective and valuable antimicrobial agent [8].

Many synthetic chemicals like diphenoxylate, loperamide and antibiotics are available for the treatment of diarrhoea but they have some side effects. The natural drugs are used as antidiarroheal drugs, which are not always free from adverse effects. Therefore, the search for safe and more effective agents has continued to be an important area of active research [9]. Since ancient times, diarrhoea has been treated orally with several medicinal plants or their extracts based on traditional medicine. Different plants such as roots of Jatropha curcus, roots and unripe fruit of Aegle marmelos, Jussiaea suffruticosa, Mangifea indica, Musa paradisiaca, Ocimum sanctum, Xanthium indicum are traditionally used [10]. The present study was undertaken to evaluate the antidiarroheal potential of Randia uliginosa Retz.

Yadav and Singh in their research paper found that about half of the world's population suffers from helminthiasis and the number is increasing day by day [11]. It is not only limited to tropical and subtropical countries but is also to endemic in many regions because of poor sanitation, poor family hygiene, malnutrition and crowded living condition. Potent anthelminthic are available today and treatment is frequent done by using different type of drugs. However the high costs of modern anthelminthic have limited effective control of the parasites. In some cases, wide spread use of low quality anthelminthic are used for the development of resistance and hence causes reduction in use of anthelminthic. It was found that plants like Benincasa hispida, Caesalpinia bonducella, Allium sativum, Zingiber officinale, Curcurbita mexicana and Ficus religiosa have anthelminthic effect [12-14].

So, on the above information demonstrate that drugs derived from plant origin have a promising future in helminthiasis, microbial and diarrheal treatment. Hence in the present study, methanol, chloroform and petroleum ether extracts of whole plant of $R$. uliginosa Retz. were examined for its antimicrobial, antidiarroheal, anthelminthic and phytochemical properties.

\section{Materials and Methods}

\section{Collection, identification and preparation of $R$. uliginosa Retz. extracts}

The whole plant of $R$. uliginosa Retz. was collected from Jahangirnagar University campus, savar, Dhaka and was identified by experts in Bangladesh National Herbarium, mirpur, Dhaka (Accession number of Randia uliginosa Retz.- 37959). The collected plant parts were thoroughly washed with water and dried in hot air oven at $60^{\circ} \mathrm{C}$ for 3 days. The dried parts were ground to coarse powder with a mechanical grinder. Plant powder sample was extracted by methanol, petroleum ether and chloroform. Extraction was performed at room temperature and preserved in petridish in refrigerator [10].

*Corresponding author: MD Al-Amin, Department of Pharmacy, Jahangirnagar University, Savar, Dhaka-1342, Bangladesh, Tel: 008801671839216; E-mail: shantopher2016@gmail.com

Received October 18, 2016; Accepted November 01, 2016; Published November 04, 2016

Citation: Hossain MDS, Al-Amin MD, Hossain MDA, Rana MDS (2016) Phytochemical, Antimicrobial, Anthelminthic and Antidiarroheal Activity of Traditional Plant Randia uliginosa Retz. Nat Prod Chem Res 4: 245. doi: 10.4172/2329-6836.1000245

Copyright: (c) 2016 Hossain MDS, et al. This is an open-access article distributed under the terms of the Creative Commons Attribution License, which permits unrestricted use, distribution, and reproduction in any medium, provided the original author and source are credited. 


\section{Source of chemicals}

All the chemicals/drugs and solvent used in this study were of analytical grade and purchased from Merck, Sigma- Aldrich, Well's Health Care Spain and Incepta Pharmaceuticals Ltd., Bangladesh.

\section{Animals and treatment}

Due to anthelminthic activity earthworms Pheretima posthuma (Annelida) were collected from moist soil at Jahangirnagar University area. Earthworms were washed with normal saline to remove soil and fecal matter and identified by Zoology Department, Jahangirnagar University. For the purpose of antidiarroheal activity Swiss albino mice of either sex were collected from Pharmacology lab, Jahangirnagar University. Animals were maintained under standard environmental conditions temperature $\left(24.0 \pm 1.0^{\circ} \mathrm{C}\right)$, relative humidity $55-65 \%$ and $12 \mathrm{~h}$ light $/ 12 \mathrm{~h}$ dark cycle. Pellets of mice foods from ICDDRB were given to the mice with fresh water ad libitum. All protocols for animal experiment were approved by the institutional animal ethical committee.

\section{Phytochemical screening}

Qualitative phytochemical tests including Dragendroff reagent for alkaloids, Molisch's test for carbohydrates, Frothin test for saponin, $\mathrm{HCl}$ test for flavonoids, Salkowski's test for steroids, Ferric chloride test for tannins, General test for glycosides were performed for the determination of presence of different class of constituents in the extract using the methods described by Ghani [10].

\section{Authentication for anthelminthic activity}

Anthelminthic activities of the plant extracts were proposed by Ajayieoba et al. [15]. This study was evaluated in adult earthworm (Pheretima posthuma) due to its anatomical and physiological resemblance with the intestinal roundworm parasites of human being. The groups of equal sized earthworms consisting of 3 earthworms in each group were released in $50 \mathrm{~mL}$ of sample with desired concentrations 10,25 and $50 \mathrm{mg} / \mathrm{mL}$. Group of earthworms in $1 \%$ Tween 80 was used as control group and group of earthworms in Piperazine citrate (10 $\mathrm{mg} / \mathrm{mL}$ ) used as reference. Observations were made for the time taken for paralysis and death of individual worms. Paralysis as said to occur when no movement of any sort could be observed except the worms was shaken vigorously. Death was concluded when the worms neither moved when shaken vigorously nor when dipped in warm water at $50^{\circ} \mathrm{C}$.

\section{Tests for antimicrobial activity}

The antimicrobial activity of the plant extract was performed by the well accepted Bauer-Kirby method [16]. The microorganisms used in the antimicrobial activity assay of the plant extracts were carried out on both Gram-positive (Bacillus subtilis, Bacillus cereus and Staphylococcus aureus) and Gram-negative (Escherichia coli, Serratia spp., Salmonella typhi and Pseudomonas spp.) bacteria. In order to avoid any type of contamination and cross contamination by the test organisms the antimicrobial screening was done in laminar air hood and all types of precautions were highly maintained. The test microorganisms were seeded into respective medium by spread plate method. Sterilized metrical (Cocksville, USA) filter paper discs were taken and soaked with $30 \mu \mathrm{L}, 20 \mu \mathrm{L}$ and $10 \mu \mathrm{L}$ of solutions of test samples. After then the filter paper discs were placed on test organism-seeded plates. Amoxicillin $(10 \mu \mathrm{L} / \mathrm{disc})$ used as standard antimicrobial disc and methanol, Chloroform and Pet. ether extracts $(10,20,30 \mu \mathrm{L} /$ disc $)$ were used as sample discs. The antibacterial assay plates were incubated at $37^{\circ} \mathrm{C}$ for $24 \mathrm{~h}$. After incubation, the antimicrobial activities of the test materials were determined by measuring the diameter of the zones of inhibition in millimeter.

\section{Tests for antidiarroheal activity}

The antidiarroheal activity of the plant extract was studied in castor oil-induced diarrhea in mice according to the method described by Shoba and Thomas [17]. Screening of the mice for the experiment was done observing the diarrhoea induced after giving $0.5 \mathrm{~mL}$ of castor oil. Mice fasted for $24 \mathrm{~h}$ were divided into control, positive control (Loperamide) and test samples (RUME, RUCL and RUPE) containing five mice in each group. Control group received $1 \%$ Tween 80 in water at the dose of $10 \mathrm{~mL} / \mathrm{kg}$ per oral. Positive control group was given Loperamide in suspension at the dose of $3 \mathrm{mg} / \mathrm{kg}$ per oral. Test groups were given the methanol, pet- ether and chloroform extracts at the doses of 250 and $500 \mathrm{mg} / \mathrm{kg}$. After 1 hour, each group was given 0.5 $\mathrm{mL}$ of castor oil orally. Then each animal was placed in a separate cage with blotting paper lined floor. The blotting papers were changed every hour. The animals were observed for the next 4 hours to record the characteristic of diarrhoea. The percent (\%) inhibition of defecation was calculated using the formula.

\section{$\%$ Inhibition of defecation $=[(\mathrm{A}-\mathrm{B}) / \mathrm{A}] \times 100$}

Where, $A=$ Mean number of defecation caused by castor oil; $\mathrm{B}=$ Mean number of defecation caused by drug or extract.

\section{Statistical analysis}

Statistical analysis was carried out using Independent- Sample T test and one way ANOVA using SPSS 16.5 for windows. The results obtained were compared with the control group. The difference were considered significant when $\mathrm{P}<0.05$.

\section{Results and Discussion}

\section{Phytochemical screening}

Preliminary phytochemical screening of the crude extracts of different parts of $R$. uliginosa Retz. revealed the presence of different kind of chemical groups that are summarized in Table 1.

Different extracts of R. uliginosa Retz. have been shown to possess phytoconstituents including carbohydrates, alkaloid, glycosides, steroids, tannins and saponin. No flavonoid was detected. These phytoconstituents present in the extracts may account for their various pharmacological activities shown in other investigations.

\section{Anthelminthic activity of $R$. uliginosa Retz.}

Earthworm used in anthelminthic activity determination of the plant extracts. Among the three different extract of $R$. uliginosa Retz. methanol extract have shown significant anthelminthic activity. Concentration $50 \mathrm{mg} / \mathrm{mL}$ of methanol extract showed maximum activity which is comparable to the standard (Piperazine citrate, $10 \mathrm{mg}$ / $\mathrm{mL}$ ) summarize in Table 2.

Piperazine citrate produces hyper polarization and reduced excitability by increasing chloride ion conductance of worm muscle membrane that leads to muscle relaxation and flaccid paralysis [18]. The methanol extracts not only demonstrated paralysis, but also caused death of worms especially at higher concentration $(50 \mathrm{mg} / \mathrm{mL})$. Phytochemical analysis of the crude extract revealed the presence of tannins among other chemical constituents. Tannins were shown to produce anthelminthic activities [19] and it is possible that tannin can bind to free proteins in the gastrointestinal tract of host animal [20] or glycoprotein on the cuticle of the parasite and may cause death [21]. 
Citation: Hossain MDS, Al-Amin MD, Hossain MDA, Rana MDS (2016) Phytochemical, Antimicrobial, Anthelminthic and Antidiarroheal Activity of Traditional Plant Randia uliginosa Retz. Nat Prod Chem Res 4: 245. doi: 10.4172/2329-6836.1000245

Page 3 of 4

\section{Antimicrobial activity determination}

The result of antimicrobial screening of different extracts of R. uliginosa has been presented in Table 3. Methanol extract of $R$. uliginosa at a dose of $30 \mu \mathrm{L} /$ disc showed maximum efficacy against all the microorganisms. Other than the methanol extract of $R$. uliginosa showed moderate activity against gram positive and gram negative bacteria. The standard, Amoxicillin, exhibited significant zone of inhibition against all the test organisms.

The methanolic extract of leaf exhibited significant antimicrobial activity and it's probably attributed to the presence of steroids [7] and saponin [6] which has been detected earlier in phytochemical screening in Table 1. On the other hand, each of the extract showed moderate antimicrobial activity against all the microorganism except Bacillus cereus. So in this context it can be concluded that $R$. uliginosa Retz. will be a greater source of antimicrobial agent.

\section{Tests for antidiarroheal activity}

In castor oil-induced diarrhea all the extracts showed dose dependent reduction in fecal dropping Table 4. Significant $(\mathrm{p}<0.01)$ level of reduction in fecal dropping was found in $250 \mathrm{mg} / \mathrm{Kg}$ methanol extract and highly significant at $500 \mathrm{mg} / \mathrm{Kg}$ methanol extract. The maximum inhibition of defecation $56.98 \%$ is observed in $500 \mathrm{mg} / \mathrm{Kg}$ extract which is comparable to standard loperamide.

\section{Conclusion}

On the basis of the findings of the present study it can be assumed that the extract of $R$. uliginosa Retz. has strong antimicrobial, antidiarroheal and anthelminthic properties which are similar to the positive controls. These results indicated that this plant could be a potential source for discovery of newer antimicrobial, antidiarroheal and anthelminthic "leads" for drug development. Present study finding supports the traditional claims and provides a scientific basis for antimicrobial, antidiarroheal and anthelminthic effect of $R$. uliginosa Retz.

\section{Future Directions}

Based upon the results of the current investigations and previous reports more specific, defined and advanced studies can be carried out. Isolation of the active constituents from the crude extracts and subsequent tests in both in vitro and in vivo studies with evaluation of their exact mode of action and chronic toxicity profile may help to reach in a concrete conclusion about the current findings.

\begin{tabular}{|c|c|c|c|c|c|c|c|}
\hline Extracts & Alkaloid Test & $\begin{array}{c}\text { Steroid } \\
\text { Test }\end{array}$ & $\begin{array}{c}\text { Glycoside } \\
\text { Test }\end{array}$ & $\begin{array}{c}\text { Saponin } \\
\text { Test }\end{array}$ & $\begin{array}{c}\text { Carbohydrate } \\
\text { Test }\end{array}$ & $\begin{array}{c}\text { Tanin } \\
\text { Test }\end{array}$ & $\begin{array}{c}\text { Flavonoid } \\
\text { Test }\end{array}$ \\
\hline RUME & + & + & + & + & + & + & + \\
\hline RUPE & + & + & + & + & + & + \\
\hline RUCF & + & + & + & + & + & + \\
\hline
\end{tabular}

+: Present; -: Absence; RUME: Methanol extract; RUPE: Pet. ether extract; RUCF: Chloroform extract

Table 1: Result of chemical group test of different extracts of $R$. uliginosa Retz.

\begin{tabular}{|c|c|c|c|}
\hline Treatment group & Doses (mg/ml) & Time for paralysis (minutes) & Time for death (minutes) \\
\hline Control & - & No paralysis & No death observed \\
\hline Piperazine citrate & 10 & $26 \pm 0.83^{* *}$ & $37 \pm 0.62^{*+}$ \\
\hline \multirow{3}{*}{ RUME } & 10 & $>90$ & $>90$ \\
\hline & 25 & $44 \pm 2.5$ & $55 \pm 3.45$ \\
\hline & 50 & $35 \pm 2.6^{* *}$ & $46 \pm 2.5^{* *}$ \\
\hline \multirow{3}{*}{ RUCL } & 10 & $>90$ & $>90$ \\
\hline & 25 & $68 \pm 4.5$ & $83 \pm 0.2$ \\
\hline & 50 & $51 \pm 4.7$ & $68 \pm 2.9$ \\
\hline \multirow{3}{*}{ RUPE } & 10 & $>90$ & $>90$ \\
\hline & 25 & $51 \pm 3.05$ & $66 \pm 2.1$ \\
\hline & 50 & $47 \pm 0.6$ & $54 \pm 2.2$ \\
\hline
\end{tabular}

The values are mean \pm SEM. " $P<0.01$, significantly different from control; Done by independent sample t-test ( $\mathrm{n}=3$ ); RUME: Methanol extract of $R$. uliginosa Retz; RUPE: Pet. ether extract of $R$. uliginosa Retz.; RUCF: Chloroform extract of $R$. uliginosa Retz.

Table 2: Anthelminthic activity of $R$. uliginosa Retz.

\begin{tabular}{|c|c|c|c|c|c|c|c|c|c|c|}
\hline \multirow{3}{*}{ Test microorganism } & \multicolumn{10}{|c|}{ Zone of inhibition in $\mathrm{mm}$} \\
\hline & \multicolumn{3}{|c|}{$\begin{array}{c}\text { Doses } \\
\mu \mathrm{l} / \mathrm{disc} \text { (RUME) }\end{array}$} & \multicolumn{3}{|c|}{$\begin{array}{c}\text { Doses } \\
\mu \mathrm{L} / \mathrm{disc}(\mathrm{RUPE})\end{array}$} & \multicolumn{3}{|c|}{$\begin{array}{c}\text { Doses } \\
\mu L / d i s c(R U C L)\end{array}$} & \multirow{2}{*}{$\begin{array}{c}\text { Standard } \\
\text { Amoxicillin } \\
10\end{array}$} \\
\hline & 10 & 20 & 30 & 10 & 20 & 30 & 10 & 20 & 30 & \\
\hline Bacillus subtilis & 7.5 & 13 & 19 & 6 & 9 & 12 & 6.5 & 7 & 9 & 28.5 \\
\hline Bacillus cereus & ND & ND & 5.5 & ND & 7.5 & 9.5 & ND & ND & 7 & 9.5 \\
\hline Staphylococcus aureus & 8.5 & 10.5 & 13 & 6.5 & 8 & 11 & 7 & 9.5 & 10.5 & 12.5 \\
\hline Pseudomonas mirabilis & 11.5 & 11 & 12.5 & 8.5 & 9 & 9.5 & 9.5 & 11 & 11.5 & 9.5 \\
\hline Escherichia coli & 12.5 & 13.5 & 14.5 & 7 & 8.5 & 9 & 8 & 9 & 11 & 18 \\
\hline Serratia spp. & 9 & 13 & 11 & 7 & 8.5 & 9 & 7.5 & 8.5 & 9 & 10.5 \\
\hline Salmonella typhi & 8.5 & 10 & 11.5 & 6.5 & 9.5 & 11 & 6.5 & 7 & 9 & 12 \\
\hline Pseudomonas spp. & 9 & 9.5 & 12.5 & 7 & 9.5 & 9.5 & 6 & 6.5 & 7.5 & 20.5 \\
\hline
\end{tabular}

*ND: Not Defined, Zone of inhibition in mm are shown by mean values; RUME: Methanol extract of $R$. uliginosa Retz.; RUPE: Pet. ether extract of $R$. uliginosa Retz.; RUCF: Chloroform extract of $R$. uliginosa Retz.

Table 3: The zone of inhibition produced by the different extracts of $R$. uliginosa Retz. against some gram positive and gram negative bacteria. 
Citation: Hossain MDS, Al-Amin MD, Hossain MDA, Rana MDS (2016) Phytochemical, Antimicrobial, Anthelminthic and Antidiarroheal Activity of Traditional Plant Randia uliginosa Retz. Nat Prod Chem Res 4: 245. doi: 10.4172/2329-6836.1000245

Page 4 of 4

\begin{tabular}{|c|c|c|c|}
\hline Group & Dose (Per oral) & No. of fecal droppings in 4 hours & \% Inhibition of defecation \\
\hline Control & - & $18.6 \pm 0.850$ \\
\hline Loperamide & $3 \mathrm{mg} / \mathrm{kg}$ & $6.2 \pm 1.284^{* *}$ \\
\hline RUME & $250 \mathrm{mg} / \mathrm{kg}$ & $10 \pm 0.42^{*}$ \\
\hline & $500 \mathrm{mg} / \mathrm{kg}$ & $8 \pm 0.59^{* *}$ \\
\hline RUCL & $250 \mathrm{mg} / \mathrm{kg}$ & $17 \pm 0.72$ \\
\hline RUPE & $500 \mathrm{mg} / \mathrm{kg}$ & $13 \pm 0.69$ \\
\hline & $250 \mathrm{mg} / \mathrm{kg}$ & $18.2 \pm 0.81$ \\
\hline
\end{tabular}

Values are mean \pm SEM, $(n=6)$; Done by Dunnet t-test using SPSS 16.6 for windows; " $p<0.05$, " $p<0.01$, significantly different from control; RUME: Methanol extract of $R$. uliginosa Retz.; RUPE: Pet. ether extract of R. uliginosa Retz.; RUCF: Chloroform extract of R. uliginosa Retz.

Table 4: Effect of different extracts of $R$. uliginosa Retz. on castor oil-induced diarrhea in mice.

\section{Acknowledgements}

This study was supported both financially and technically by Phytochemical and Pharmacological Lab, Department of Pharmacy, Faculty of Life Science, Jahangirnagar University, Savar, Dhaka.

\section{References}

1. Newman DJ, Cragg GM, Snader KM (2003) Natural products as sources of new drugs over the period 1981-2002. J Nat Prod 66: 1022-1037.

2. Koehn FE, Carter GT (2005) The evolving role of natural products in drug discovery. Nat Rev Drug Discovery 4: 206-220.

3. Kumarasamy KK, Toleman MA, Walsh TR, Bagaria J, Butt F, et al. (2010) Emergence of a new antibiotic resistance mechanism in India, Pakistan, and the UK: a molecular, biological, and epidemiological study. The Lancet Infectious Disease 10: 597-602.

4. Zuo YG, Meng FY, Hao XY, Zhang YL, Wang GC, et al. (2008) Antibacterial alkaloids from chelidonium majus linn. (papaveraceae) against clinical isolates of methicillin-resistant staphylococcus aureus. J Pharm Pharm Sci 11: 90-94.

5. Cushnie TPT, Lamb AJ (2005) Antimicrobial activity of flavonoids. International Journal of Antimicrobial Agents 26: 343-356.

6. Avato P, Bucci R, Tava A, Vitali C, Rosato A, et al. (2006) Antimicrobial activity of saponins from Medicago sp.: structure-activity relationship. Phytother Res 20: 454-457.

7. Taleb-Contini SH, Salvador MJ, Watanabe E (2003) Antimicrobial activity of flavonoids and steroids isolated from two Chromolaena species. Braz J Pharma Sci 39: 403-408.

8. Abu-Shanab BG, Adwn D, Safiya A, Jarrar N, Adwan K (2004) Antimicrobial activities of some plant extracts utilized in popular medicine in Palestine. Turkish Journal of Biology 28: 99-102.

9. Maiti A, Dewanjee S, Mandal SC (2007) In Vivo Evaluation of Antidiarrhoeal Activity of the Seed of Swietenia macrophylla King (Meliaceae). Tropical Journal of Pharmaceutical Research 6: 711-716.

10. Ghani A (2003) Medicinal Plants of Bangladesh with chemical constituents and uses. 2nd edn. Asiatic Society of Bangladesh, 5 old Secretariat Road, Nimtali, Dhaka, Bangladesh.

11. Yadav $P$, Singh $R$ (2011) A review on anthelminthic drugs and their future scope. International Journal of Pharmacy and Pharmaceutical Science 3: 17-21.

12. Bhattacharjee C, Debjit B, Tiwari P, Tripathi KK, Dutta AS (2010) In Vitro anthelmintic activity of Benincasa hispida (Petha) thumb leaves. International Journal of Pharma and Bio Sciences 1: 9.
13. Wadkar GH, Kane SR, Matapati SS, Hogade MG (2010) In vitro anthelmintic activity of Caesalpinia bonducella (Linn) Flem Leaves. Journal of Pharmacy Research 3: 926-927.

14. Iqbal Z, Nadeem QK, Khan MN, Akhtar MS, Waraich FN (2001) In Vitro Anthelmintic Activity of Allium sativum, Zingiber officinale, Curcurbita mexicana and Ficus religiosa. Int J Agri Biol 3: 454-457.

15. Ajaiyeoba EO, OnochaPA, Olarenwaju OT (2001) In-vitro anthelmintic properties of Buchholzia coiaceae and Gynandropsis gynandra extract. Pharm Biol 39: 217 220.

16. Bayer AW, Kirby WMM, Sherris JC, Turck M (1966) Antibiotic susceptibility testing by a standardized single disc method. Am J Clin Pathol 45: 493-496.

17. Shoba FG, Thomas M (2001) Study of antidiarrhoeal activity of four medicinal plants in castor-oil induced diarrhoea. Journal of Ethnopharmacology 76: 73 76.

18. Martin RJ (1985) Y-Aminobutyric acid and Piperazine activated single channe currents from Ascaris suum body muscle. Br J Pharmacol 84: 445-461.

19. Niezen JH, Waghorn GC, Charleston (1995) Growth and gastrointestina nematode parasitism in lambs grazing either Lucerne (Medicago sativa or Hedysarum coronarium), which contains condensed tannins. J Agri Sci 125: 281 289

20. Athnosiadou S, Kyriazakis I, Jackson F, Coop RL (2001) Direct anthelmintic effects of condensed tannins towards different gastrointestinal nematodes of sheep: In vivo studies. Vet Parasitol 99: 205-219.

21. Thompson DP, Geary TG (1995) The structure and function of helminthes surfaces. Biochemistry and Molecular Biology of Parasites 1: 203-232. 